\title{
The use of 16S rDNA sequence analysis to investigate the phylogeny of Leptospiraceae and related spirochaetes
}

\author{
JoHN V. HOOKEY, ${ }^{1 *} \dagger$ JuLIA BRYDEN ${ }^{2}$ and LAURENCE GaTEHOUSE ${ }^{2}$ \\ ${ }^{1}$ PHLS Leptospira Reference Laboratory, FAO/WHO Collaborating Centre, County Hospital, \\ Hereford HRI 2ER, UK \\ ${ }^{2}$ Department of Biological Sciences, The Science Laboratories, University of Durham, Durham DH1 3LE, UK
}

(Received 18 May 1993; revised 5 July 1993; accepted 15 July 1993)

\begin{abstract}
The 16S rDNA sequences from 15 Leptospiraceae were determined by automated PCR-directed cycle sequencing. Nucleotide comparisons, including those from published sequences for Leptospira canicola Moulton and Serpulina spp., were used to construct phylogenetic trees. Serpulina hyodysenteriae and $S$. innocens were related to each other but were distinct from the Leptospiraceae comprising Leptospira parva incertae sedis (Turneria parva $\mathrm{H}$ ), Leptonema illini and Leptospira spp. The pathogenic and the saprophytic leptospires were distinct and separated from each other. Leptospira inadai occupied an intermediate position between the two forms. The pathogens formed three groups. Group I was represented by $L$. interrogans sensu stricto and $L$. kirschneri, Group II by $L$. weilii, $L$. borgpetersenii and $L$. santarosai, and Group III comprised $L$. noguchii and $L$. meyeri. The saprophytic species, $L$. wolbachii and $L$. biflexa sensu stricto shared about $99 \%$ sequence similarity. The freshwater isolates were distinct from the marine isolate $L$. biflexa sensu lato ancona Ancona Porto.
\end{abstract}

\section{Introduction}

The Leptospiraceae, comprising Leptospira and Leptonema, are motile, flexible helical aerobic spirochaetes. Some are pathogenic for man and animals and others are free-living in soil, fresh- and salt-waters (Johnson \& Faine, 1984). Their classification remains problematic and two different classifications co-exist, one based on serological affinities and the other on genetic relatedness (Kmety \& Dikken, 1988; Yasuda et al., 1987). Traditionally, two species Leptospira interrogans sensu lato (the pathogens) and L. biflexa sensu lato (the so-called 'saprophytes') could be delineated on the basis of their DNA base composition and a limited number of phenotypic characteristics (Johnson \& Faine, 1984), and each in turn was arranged into the basic taxon of serovar; L. interrogans has 202 serovars and L. biflexa 65 (Kmety \& Dikken, 1988). Recently eight new species, $L$. borgpetersenii, L. inadai, L. meyeri, L. noguchii, $L$.

*Author for correspondence. Tel. +4481 2004400 ext. 3971; fax +44812007874 .

†Present address: Central Public Health Laboratory Service, Division of Microbiological Reagents, Molecular Biology Laboratory, 61 Colindale Avenue, London NW9 5DF, UK. santarosai, L. weilii, L. wolbachii (Yasuda et al., 1987) and L. kirschneri (Ramadass et al., 1992) were described on the basis of DNA:DNA homology studies. Similarly, Ramadass et al. (1990) revealed that the L. biflexa sensu lato 'complex' comprised at least six DNA homology groups.

Comparative sequencing of small subunit rRNA is now the method of choice for constructing higher level classifications (Woese, 1987). Oligonucleotide cataloguing and, more recently, reverse transcriptase sequencing of $16 \mathrm{~S}$ rRNA showed that the spirochaetes were a phylogenetically distinct group subdivided into the Spirochaetaceae (Borrelia, Cristispira, Serpulina, Spirochaeta and Treponema) and the Leptospiraceae [Leptospira and Leptonema (Paster et al., 1984, 1991)].

In view of the limited amount of information available with regard to the evolutionary relatedness of leptospires, the intent of this study was to establish more fully the phylogenetic relationships between members of the family Leptospiraceae on the basis of 16S rDNA sequence analysis.

\section{Methods}

Bacterial strains and culture. Fifteen strains of Leptospiraceae (Table 1) were cultured in EMJH broth (Ellinghausen \& McCullough, 1965) 
Table 1. Bacterial strains examined and their rDNA sequence accession numbers

\begin{tabular}{|c|c|c|c|}
\hline Species & Serovar Reference Strain* & Source $\dagger$ & Accession No. $\ddagger$ \\
\hline L. borgpeterseniiß & $\begin{array}{l}\text { javanica Veldrat Batavia } 46 \text { (ATCC } \\
43292) \|\end{array}$ & & Z21630 \\
\hline L. interrogans sensu stricto§ & icterohaemorrhagiae RGA\|ף & $\begin{array}{l}\text { W. J. Terpstra (Royal Tropical } \\
\text { Institute, Meibergdreef, } \\
\text { Amsterdam, The Netherlands) }\end{array}$ & Z12817 \\
\hline L. noguchii§ & panama CZ 214 (ATCC 43288)\| & W. J. Terpstra & Z21635 \\
\hline L. santarosai§ & shermani $1342 \mathrm{~K}$ (ATCC 43286)\| & & Z21649 \\
\hline L. weiliis & $\begin{array}{l}\text { celledoni Celledoni (ATCC } \\
\text { 43285)\| }\end{array}$ & & Z21637 \\
\hline L. kirschneri§ & cynopteri $3522 \mathrm{CT}$ & W. J. Terpstra & $\mathrm{Z} 21628$ \\
\hline L. inadai§ & lyme (ATCC 43289)\| & $\begin{array}{l}\text { A. F. Kaufmann (Centres for } \\
\text { Disease Control, Atlanta, GA, } \\
\text { USA) }\end{array}$ & Z21634 \\
\hline L. biflexa sensu stricto** & patoc Patoc $1 \|$ & $\begin{array}{l}\text { B. Cacciapuoti (Instituto } \\
\text { Superiore di Sanitá, Roma, } \\
\text { Italy) }\end{array}$ & $\mathrm{Z12821}$ \\
\hline L. meyeri** & ranarum ICF (ATCC 43287) & W. J. Terpstra & Z21648 \\
\hline L. wolbachii** & $c d c$ Biflexa CDC (ATCC 43284)\| & B. Cacciapuoti & Z21638 \\
\hline L. parva incertae sedis** & & $\begin{array}{l}\text { W. A. Ellis (Veterinary Research } \\
\text { Laboratories, Belfast, UK) }\end{array}$ & Z21636 \\
\hline Leptonema illini** & & $\begin{array}{l}\text { K. Hovind-Hougen (National } \\
\text { Veterinary Laboratory, } \\
\text { Copenhagen, Denmark) }\end{array}$ & Z21632 \\
\hline L. biflexa sensu lato* & $\left.\begin{array}{l}\text { ancona Ancona Porto } \\
\text { canela Canela } \\
\text { jequitaia Jequitaia }\end{array}\right\}$ & B. Cacciapuoti & $\begin{array}{l}\text { Z21629 } \\
\text { Z21631 } \\
\text { Z21633 }\end{array}$ \\
\hline
\end{tabular}

*Designation based on serological studies (Kmety \& Dikken, 1988).

$\dagger$ Unless otherwise stated, the source of strains was L. H. Turner (Leptospira Reference Laboratory, FAO/WHO Collaborating Centre, County Hospital, Hereford HR1 2ER, UK).

$\ddagger$ Accession numbers were obtained from the EMBL data library. The accession number for canicola Moulton was X17547 (Fukunaga $e t$ al., 1990) and those for S. hyodysenteriae and S. innocens were M57741 and M57744, respectively (Stanton et al., 1991).

§Species considered to be pathogenic for man and animals (Yasuda et al., 1987).

II Reference strains assigned to a species on the basis of DNA hybridization (hydroxyapatite method; Yasuda et al., 1987).

T Reference strains assigned to a species on the basis of DNA hybridization (slot-blot method; Ramadass \& Marshall, 1990; Ramadass et al., 1992).

** Species considered to be saprophytic (Yasuda et al., 1987; Johnson \& Faine, 1984).

at $30^{\circ} \mathrm{C}$ for $7-10 \mathrm{~d}$ and checked for the presence of contaminating aerobic bacteria by overnight culture on $8 \%(\mathrm{w} / \mathrm{v})$ horse-blood agar at 30 and $37^{\circ} \mathrm{C}$.

Isolation of chromosomal DNA. Chromosomal DNA was prepared by the method of Hookey \& Palmer (1991).

Preparation of PCR-amplified $16 S$ rDNA. DNA was amplified by PCR using a primer pair specific for 16S rDNA [pU (34-53): Hookey, 1992; $\mathrm{pH}^{-}$: Edwards et al., 1989]. Primer oligonucleotides were made using a DNA-synthesizer (model 381, Applied BioSystems) and the oligomers purified according to the manufacturer's recommendations. Reactions were performed on a Perkin-Elmer 480 Thermal Cycler in sterile thin-walled tubes that contained approximately $100 \mathrm{ng}(1-2 \mu \mathrm{l})$ chromosomal DNA, the reaction mix comprising $10 \mu \mathrm{l}$ of $10 \times \mathrm{PCR}$

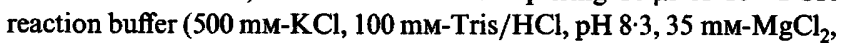
$0.01 \%$ gelatin; EIA grade, Bio-Rad), $200 \mu \mathrm{M}$ each of dATP, dCTP, dGTP and dUTP (Pharmacia), 100 pM of each primer. Glycerol at $10 \%$ (w/v), 2.5 U AmpliTaq DNA polymerase (ILS Ltd) and sterile 'Millipure' water were added to a final volume of $100 \mu$ l. The reaction mix was overlayered with $150 \mu \mathrm{l}$ mineral oil (ILS Ltd). A reaction mix containing no DNA served as a negative control.

Following denaturation of the DNA template at $95^{\circ} \mathrm{C}$ for $5 \mathrm{~min}$, the temperature was lowered to and held at $80^{\circ} \mathrm{C}$ while the reaction mix was added to the DNA. Thermal cycling $(\times 30)$ then proceeded at $95^{\circ} \mathrm{C}$ for $40 \mathrm{~s}, 55^{\circ} \mathrm{C}$ for $25 \mathrm{~s}$ and $72^{\circ} \mathrm{C}$ for $3 \mathrm{~min}$. A final step at $72^{\circ} \mathrm{C}$ for $10 \mathrm{~min}$ was included.

The amplified DNA was extracted once with an equal volume of phenol/chloroform, precipitated in the presence of 0.1 vols $3.0 \mathrm{M}$ sodium acetate ( $\mathrm{pH} \mathrm{5 \cdot 2)}$ and 3 vols absolute ethanol (AnalaR; BDH), and redissolved in $25 \mu$ l Millipure water.

Purification of $16 S$ rDNA product. The amplified 16S rDNA was purified prior to DNA sequencing according to standard protocols (Sambrook et al., 1989). Briefly, unwanted primers, deoxyribonucleotides and DNA polymerase were separated from the amplification product by electroelution through a $1.0 \%(\mathrm{w} / \mathrm{v})$ agarose gel (MB grade; Bio-Rad) at $100 \mathrm{~mA}$ onto activated DEAE-cellulose membranes (NA-45; Schleicher \& Schuell).

Automated PCR-directed cycle sequencing. The purified doublestranded DNA template was sequenced using a Taq DyeDeoxy Terminator Cycle Sequencing kit (Applied BioSystems) on an ABI model 373-A automated fluorescent DNA sequencer according to the manufacturer's instructions. The primers used were $\mathrm{pC}, \mathrm{pD}, \mathrm{pD}^{-}, \mathrm{pH}^{-}$ (Edwards et al., 1989), pU (Hookey, 1992), p4 [5'...TAA GGG TTG CGC TCG TTG ... $\left.3^{\prime}(1132-1115)\right]$ and pE4 [ $5^{\prime} \ldots$ CGC AAC GAG CGC AAC CCT ... 3' (1113-1130)].

The thermal cycle sequencing programme used on the PharmaciaLKB thermal cycler was $96^{\circ} \mathrm{C}$ for $30 \mathrm{~s}, 50^{\circ} \mathrm{C}$ for $40 \mathrm{~s}$, and a $4 \mathrm{~min}$ 

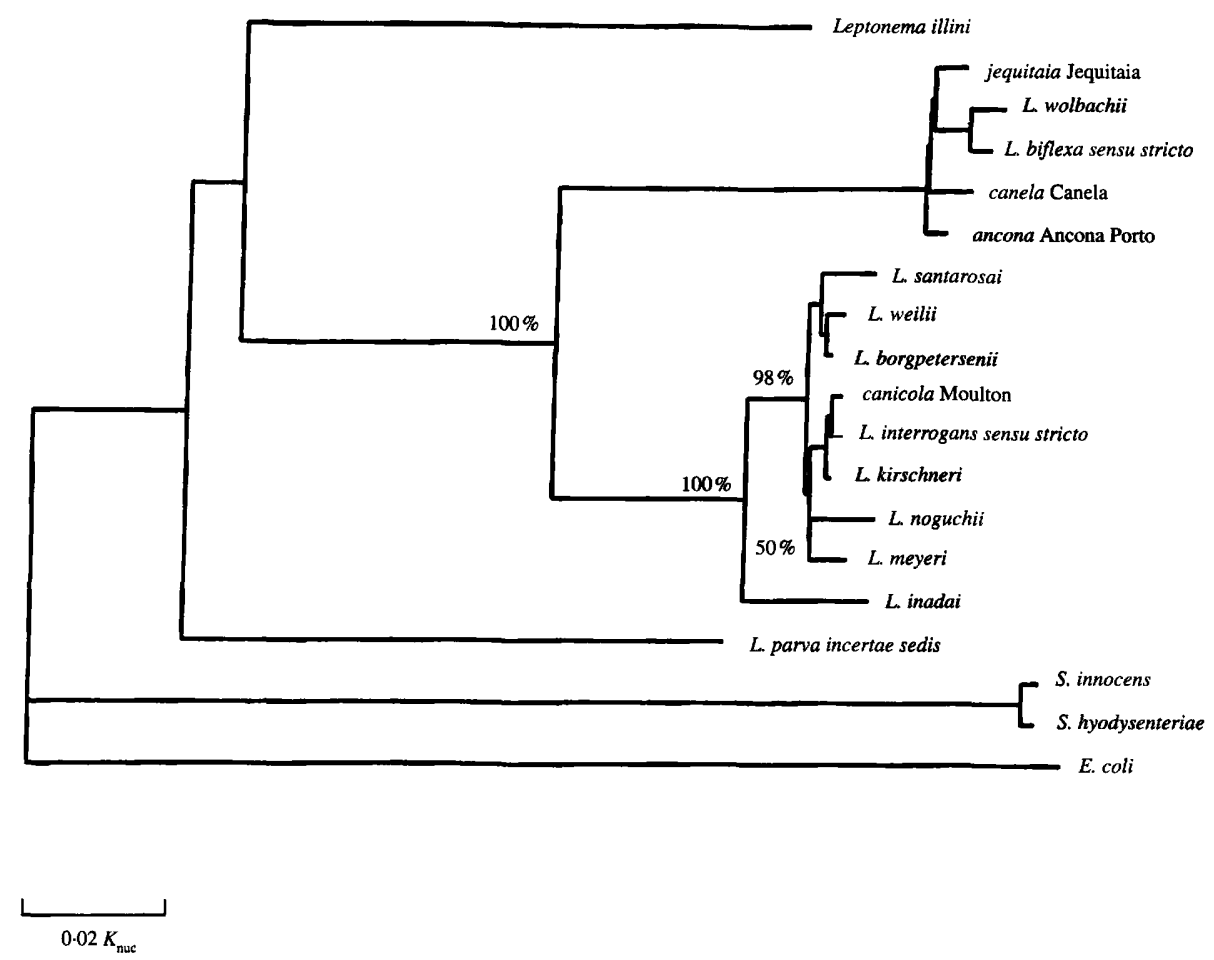

Fig. 1. Unrooted consensus Jukes \& Cantor (1969) correction and Fitch \& Margoliash (1967) distance tree showing the position of Leptospiraceae and related spirochaetes. Bootstrap percentages for the following were: $L$. interrogans sensu stricto and canicola Moulton, $78 \% ;$ L. kirschneri, $98 \% ;$ L. noguchii and L. meyeri, 34\%; L. santarosai, $67 \%$; L. weilii and L. borgpetersenii, $75 \%$; ancona Ancona Porto, $100 \%$; jequitaia Jequitaia, $39 \%$; canela Canela, $27 \%$; L. biflexa sensu stricto and L. wolbachii, $96 \% ;$ L. parva incertae sedis, $56 \%$; Leptonema illini, $100 \% ; E$. coli, $97 \% ;$ S. hyodysenteriae and $S$. innocens, $100 \%$. The bootstrap percentages quoted are the percentage times a taxa at that node occurred. The scale bar represents 0.02 substitutions per sequence position $\left(K_{\text {nuc }}\right)$.

extension at $60^{\circ} \mathrm{C}$ for 25 cycles. Following amplification, excess DyeDeoxy Terminators were removed from the sequencing reaction by spin-column centrifugation according to the manufacturer's instructions (Bio-Spin 30 chromatographic column; Bio-Rad), ethanolprecipitated, dried and redissolved in $4 \mu$ l loading buffer. DNA fragments were separated on conventional $0.4 \mathrm{~mm}, 6.0 \%(\mathrm{w} / \mathrm{v})$ denaturing acrylamide gels at $100 \mathrm{~W}$.

Analysis of sequence data. The primary sequence data have been deposited with the GenBank/EMBL data libraries and the accession numbers are given in Table 1 . Sequences were aligned using the MULTaLIN program (Corpet, 1988; Cherwell Scientific Publishing Ltd, Oxford, UK). The 11 Leptospira spp., Leptonema illini, four reference serovars and two related spirochaetes were checked against the secondary structure model of Neefs et al. (1991). Those regions of hypervariability and base positions that could not be aligned unambiguously were omitted from the final alignment (about 140 nucleotides similar to those omitted by Paster et al., 1991). A total of 1339 bases comprised the final alignment; this is available from the authors on request.

Distance matrices. Distance matrices were constructed from bootstrapped data by DNADIST contained in the Phylogenetic Inference Package, PHYLIP 3.4 (J. Felsenstein, University of Washington, USA) and user trees computed using neighbour-joining (NEIGHBOR; Saitou \& Nei, 1987), and Fitch-Margoliash (FITCH; Fitch \& Margoliash, 1967) using either the Jukes \& Cantor (1969) correction for multiple substitutions or the maximum likelihood method (DNAML) employing the empirical frequencies of the bases as given in the input data. Majority-rule consensus trees were computed from the user trees using the CONSENSE program.
The bootstrap percentages quoted for a species or serovar in the legend to Fig. 1 are the percentage times that a taxa to the right of that node occurred and it provides some indication of the stability of the branching order.

Parsimony. Bootstrapped $(\times 100)$ sequence data was analysed using the DNAPARS and CONSENSE programs.

Reliability of trees. Majority-rule consensus trees were produced from bootstrapped data sets via distance matrix and parsimony treeing. The aligned sequence data was resampled $\times 100$ using a general bootstrapping program, SEQBOOT. Parsimony and distance metric consensus trees were evaluated for statistical significance using the modified test of Templeton (Templeton, 1983; Felsenstein, 1985) by invoking the user tree option in DNAPARS. The topologies were not significantly different and only one is presented (Fig. 1). Specific topologies are available from the authors on request.

\section{Results and Discussion}

Sequencing generated between 1451 and 1374 bases (97-92\%) of 16S rDNA sequence for the 15 strains studied. The matrix of evolutionary distance $\left(K_{\text {nuc }}\right)$ values are given in Table 2.

Phylogenetic trees based on sequence data must be interpreted with caution (Felsenstein, 1988). In this study, bootstrapped data, out-grouping to $E$. coli and the statistical comparisons of topologies indicated that the 


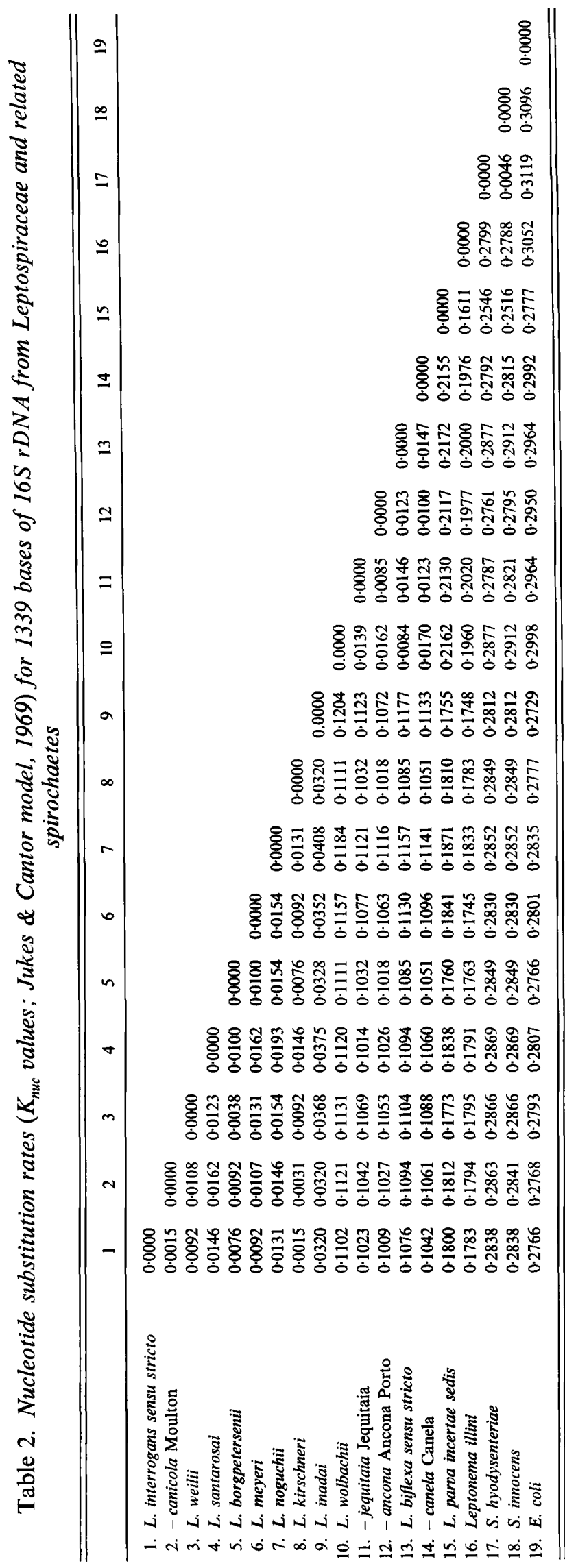

branching order was reliable and that the consensus tree (Fig. 1) may be a good reconstruction of the relationships between the Leptospiraceae. The overall topology between the Serpulina spp., Leptonema illini, Leptospira interrogans and L. biflexa was identical to that given by Paster et al. (1991).

The consensus trees summarize the evolutionary relationships between taxa examined and their relative positions (Fig. 1). The aetiological agent of swine dysentery, Serpulina hyodysenteriae and the saprophyte S. innocens were distinct species (Stanton et al., 1991; Fig. 1; Table 2). Their exact phylogenetic position relative to the Leptospiraceae was not resolved by the current data and their position as an in-group in Fig. 1 was merely one of convenience.

L. parva incertae sedis was isolated as a contaminant in EMJH medium (Hovind-Hougen et al., 1981). Morphologically it is similar to the leptospires, has phenotypic characteristics of both the pathogenic and the saprophytic forms, low DNA:DNA similarity values compared to other Leptospira sp. (Yasuda et al., 1987) and comparatively large evolutionary distance values (Table 2). Collectively these data support the ad hoc proposal for a new genus, Turneria (' $L$ '. parva reference strain $\mathrm{H}$; Anon., 1992).

Leptonema illini was unexpectedly more related to the Leptospiraceae than was Leptospira parva incertae sedis and the sequence data gave qualified support to it being a distinct genus (Hovind-Hougen, 1979).

The pathogenic leptospires (Table 1) have been divided broadly into two groups ( $L$. interrogans and L. kirschneri, and $L$. weilii, $L$. borgpetersenii and $L$. santarosai) on the basis of such criteria as $\mathrm{G}+\mathrm{C}$ content, sensitivity to 2,6diaminopurine, lipase production (Haapala et al., 1969), DNA homologies (Ramadass et al., 1992) and the presence or absence of DNA fragments hybridizing on Southern blots to the $s p h \mathrm{~A}$ sphingomyelinase gene (Segers et al., 1992). These results are in agreement with those presented here though a third group, L. noguchii and L. meyeri, may be delineated (Fig. 1). Although the relatively low percentage bootstrap value indicated branching instability (Fig. 1), the $L$. noguchii and $L$. meyeri group shared a $16 \mathrm{~S}$ rDNA sequence value of approximately $96.6 \%$, an evolutionary distance value of 0.0154 (Table 2) and a mol\% G + C of about $35.0 \%$ (Yasuda et al., 1987). Sequence values of between 95 and $97 \%$ are generally expected for different species within a genus (Paster \& Dewhirst, 1988; Dewhirst et al., 1989). The strain $L$. meyeri ranarum ICF was isolated from the kidneys of a leopard frog (Rana pipiens) and had the characteristics of being a saprophyte, growing at $13{ }^{\circ} \mathrm{C}$ and being unable to establish leptospirosis in laboratory animals (Diesch et al., 1966). Yet it formed part of a pathogenic 'complex', being sensitive to 8-azaguanine, 
2,6-diaminopurine and copper sulphate (Brendle et al., 1974; Diesch et al., 1966; Ellinghausen, 1968). Furthermore, it was positive in a PCR test for pathogenic leptospires (Hookey, 1992), gave multiple putative sphingomyelinase gene patterns similar to strains of a pathogenic nature (Segers et al., 1992), an EcoR1 $0.75-0.8 \mathrm{~kb} 16 \mathrm{~S}$ rDNA fragment resembling the pathogens on 'ribotyping' (Hookey, 1993) and it occupied a central phylogenetic position within the pathogenic domain. In view of the weight of evidence, L. meyeri should be regarded as being related to the pathogens.

The type strain of the genus $L$. interrogans icterhaemorrhagiae RGA and L. kirschneri had about $99.84 \%$ sequence similarity and could be regarded as belonging to the same species. However, DNA:DNA hybridization values (approximately $31 \cdot 1 \%$ ) have clearly established both as separate entities (Yasuda et al., 1987; Ramadass et al., 1992). Similar results were also in evidence between the saprophytes, $L$. weilii and $L$. biflexa sensu stricto (Fig. 1; Table 2; Yasuda et al., 1987). The lack of correlation between 16S rDNA sequence similarity and DNA hybridization data is not unknown (Ash et al., 1991; Boddinghaus et al., 1990; Collins et al., 1989; Whiley et al., 1990) and it has been suggested that such recently diverged strains should be treated as part of a single rRNA species or super-species complex (Fox et al., 1992). In contrast, the serovar canicola may be regarded as a member of $L$. interrogans sensu stricto on both DNA relatedness ( $>70 \%$, Ramadass et al., 1992) and 16S rDNA sequence identity (Table 2 ).

The group, $L$. weilii, $L$. borgpetersenii and $L$. santarosai have between 68 and $62 \%$ DNA:DNA relatedness to each other (Yasuda et al., 1987), an average $K_{\text {nuc }}$ value of $\mathbf{0 . 0 0 8 7}$ (Table 2) and similar G+C content (Yasuda $e t$ al., 1987). This level of $16 \mathrm{~S}$ rDNA sequence divergence supports their division into three species.

The phylogenetic position of $L$. inadai was such that it bisected the pathogenic and saprophytic domains. Whether this represents an emerging subline or a transitionary stage between the two domains is not known. The organism was isolated from a skin biopsy of a patient with Lyme disease (Schmid et al., 1986), was pathogenic for laboratory animals, had the biological, genetic (Yasuda et al., 1987) and fatty acid composition (Johnson et al., 1970; Cacciapuoti et al., 1991) of both the pathogens and the saprophytes, yet was akin to the free-living leptospires in not having putative sphingomyelinase genes (Segers et al., 1992).

There was clear division between $L$. biflexa sensu stricto and the salt-water isolate L. biflexa sensu lato ancona Ancona Porto (Fig. 1). These strains were separated by a $K_{\text {nuc }}$ value of 0.0085 (Table 2) and share only $3.8 \%$ DNA hybridization (Yasuda et al., 1987). Also, L. biflexa was assigned to genetic group 5 and that of L. biflexa ancona Ancona Porto to group 4 on DNA relatedness (Ramadass et al., 1992). Consistent with this scenario would be a proposal to assign $L$. biflexa sensu lato ancona Ancona Porto to a new species.

In the absence of hybridization data and the relatively low consensus among the bootstrapped 16S rDNA sequence data sets (Fig. 1), little can be inferred of the genetic relationships between the freshwater isolates, $L$. biflexa sensu lato canela Canela and L. biflexa sensu lato jequitaia Jequitaia other than that they were distinct from each other and from the other strains examined.

In this study a comparative 16S rDNA sequencing analysis of all recognized species of Leptospiraceae revealed that the pathogenic species, though distinct from each other, comprised three groups and that the saprophytes, as currently circumscribed by $L$. biflexa sensu stricto and $L$. wolbachii, comprised a heterogeneous complex requiring further analyses. The lineages for $L$. inadai and $L$. parva incertae sedis were distinct. There was a correlation between groupings formed on total DNA hybridizations and those on 16S rDNA sequence data that may provide the framework for a natural classification of these spirochaetes.

The authors would like to thank Drs C. J. Duggleby, and N. A. Saunders for critical reading of this manuscript.

\section{References}

Anon. (1992). International Committee on Systematic Bacteriology Subcommittee on the Taxonomy of Leptospira: minutes of the meetings, minute 10; 13-15 September 1990, Osaka, Japan. International Journal of Systematic Bacteriology 42, 330-334.

Ash, C., Farrow, J. A. E., Dorsch, M., Stackebrandt, E. \& Collins, M. D. (1991). Comparative analysis of Bacillus anthracis, Bacillus cereus, and related species on the basis of reverse transcriptase sequencing of 16S rRNA. International Journal of Systematic Bacteriology 41, 343-346.

Boddinghaus, B., Wolters, J., Heikens, W. \& Bottger, E. C. (1990). Phylogenetic analysis and identification of different serovars of Mycobacterium intracellulare at the molecular level. FEMS Microbiology Letters 70, 197-204.

Brendle, J. J., Rogul, M. \& Alexander, A. D. (1974). Deoxyribonucleic acid hybridisation among selected leptospiral serotypes. International Journal of Systematic Bacteriology 24, 205-214.

Cacciapuoti, B., Ciceroni, L. \& Barbini, D. A. (1991). Fatty acid profiles, a key for the classification of strains of the family Leptospiraceae. International Journal of Systematic Bacteriology 41, 295-300.

Collins, M. D., Ash, C., Farrows, J. A. E., Wallbanks, S. \& WILLIAMs, A. M. (1989). 16S rRNA sequence analysis of lactococci and related taxa. Description of Vagococcus fuvialis gen. nov., sp. nov. Journal of Applied Bacteriology 67, 453-460.

CORPET, F. (1988). Multiple sequence alignment with hierarchical clustering. Nucleic Acids Research 16, 10881-10890.

Diesch, S. L., McCulloch, W. F., Braun, J. L. \& Ellinghausen, H. C., JR (1966). Leptospires isolated from frog kidneys. Nature, London 209, 939-940.

Dewhirst, F. E., PAster, B. J. \& Bright, P. L. (1989). Chromobacterium, Eikenella, Kingella, Neisseria, Simonsiella, and Vitreoscilla species comprise a major branch of the beta group Proteobacteria by 16 S ribosomal ribonucleic acid sequence comparison: transfer of Eikenella and Simonsiella to the family 
Neisseriaceae (amend). International Journal of Systematic Bacteriology 39, 258-266.

Edwards, U., Rogall, T., Blocker, H., Emde, M. \& Bottger, E. C. (1989). Isolation and direct complete nucleotide determination of entire genes. Characterization of a gene coding for $16 \mathrm{~S}$ ribosomal RNA. Nucleic Acids Research 17, 7843-7853.

Ellinghausen, H. C., JR (1968). Cultural and biochemical characteristics of a leptospire from frog kidney. Bulletin of the Wildlife Disease Association 4, 41-40.

Ellinghausen, H. C. \& MCCullough, W. G. (1965). Nutrition of Leptospira pomona and growth of 13 other serotypes: fractionation of oleic albumin complex and a medium of bovine albumin and polysorbate 80. American Journal of Veterinary Research 26, 45-51.

FElsensteIn, J. (1985). Confidence limits on phylogenies with a molecular clock. Systematic Zoology 34, 152-161.

Felsenstein, J. (1988). Phylogenies from molecular sequencies: inferences and reliability. Annual Review of Genetics 22, 21-65.

Firch, W. M. \& MARGOLIASH, E. (1967). Construction of phylogenetic trees. A method based on mutation distances as estimated from cytochrome $c$ sequences is of general applicability. Science 155, 279-284.

Fox, G. E., Wisotzkey, J. D. \& JurtshuK, P., JR (1992). How close is close: 16S rRNA sequence identity may not be sufficient to guarantee species identity. International Journal of Systematic Bacteriology $\mathbf{4 2}$, 166-170.

Fukunaga, M., Horie, I., Okuzako, N. \& Mifuchi, I. (1990). Nucleotide sequence of a 16S rRNA gene for Leptospira interrogans serovar canicola strain Moulton. Nucleic Acids Research 18, 366.

Haapala, D. K., Rogul, M., Evans, L. B. \& Alexander, A. D. (1969). Deoxyribonucleic acid base composition and homology studies of Leptospira. Journal of Bacteriology 98, 421-428.

HoOKEY, J. V. (1992). Detection of Leptospiraceae by amplification of 16S ribosomal DNA. FEMS Microbiology Letters 90, 267-274.

HookeY, J. V. (1993). Characterization of Leptospiraceae by 16S DNA restriction fragment length polymorphisms. Journal of General Microbiology 139, 1681-1689.

HoOKeY, J. V. \& Palmer, M. F. (1991). A comparative investigation and identification of Leptospira interrogans serogroup icterohaemorrhagiae strains by monoclonal antibody and DNA fingerprint analysis. Zentralblatt für Bakteriologie 272, 185-199.

Hovind-Hougen, K. (1979). Leptospiraceae, a new family to include Leptospira Noguchi 1917 and Leptonema gen. nov. International Journal of Systematic Bacteriology 29, 245-251.

Hovind-Hougen, K., Ellis, W. A. \& Birch-Andersen, A. (1981). Leptospira parva. sp. nov.; some morphological and biological characters. Zentralblatt für Bakteriologie. Parasitenkunde Infektionskrankheiten und Hygiene Abteilung I Originale Reihe A 250, 343-354.

Johnson, R. C. \& FaINE, S. (1984). Genus I. Leptospira Noguchi 1917, $755^{\mathrm{AL}}$. In Bergey's Manual of Systematic Bacteriology, vol. 1, pp. 62-67. Edited by N. R. Krieg \& J. G. Holt. Baltimore/London: Williams \& Wilkins.

Johnson, R. C., Livermore, B. P., Walby, J. K. \& Jenkin, H. M. (1970). Lipids of parasitic and saprophytic leptospires. Infection and Immunity 2, 286-291.

Jukes, T. H. \& CANTOR, C. R. (1969). Evolution of protein molecules. In Mammalian Protein Metabolism, pp. 21-132. Edited by H. N. Munro. New York: Academic Press.

KMETY, E. \& DikKen, H. (1988). Revised list of Leptospira serovars. I Alphabetical order and II Chronological order. In International
Committee on Systematic Bacteriology of the International Union of Microbiological Societies Subcommittee on the Taxonomy of Leptospira. Edited by E. Kmety \& H. Dikken. Groningen: University Press.

Neefs, J.-M., van der Peer, Y., De Rijk, P., Goris, A. \& De Wachter, R. (1991). Compilation of small ribosomal subunit RNA sequences. Nucleic Acids Research 19 (supplement), 1987-2015.

Paster, B. J. \& Dewhirst, F. E. (1988). Phylogeny of campylobacters, wolinellas, Bacteroides gracilis, and Bacteroides ureolyticus by $16 \mathrm{~S}$ ribosomal ribonucleic acid sequencing. International Journal of Systematic Bacteriology 38, 56-62.

Paster, B. J., Stackebrant, E., Hespell, R. B., Hahn, C. M. \& WOESE, C. R. (1984). The phylogeny of the spirochetes. Systematic and Applied Microbiology 5, 337-351.

Paster, B. J., Dewhirst, F. E., Weisburg, W. G., Tordoff, L. A., Fraser, G. J., Hespell, R. B., Stanton, T. B., Zablen, L., MANDelCo, L. \& Woese, C. R. (1991). Phylogenetic analysis of the spirochetes. Journal of Bacteriology 173, 6101-6109.

Ramadass, P., Jarvis, B. D. W., Corner, R. J., Cinco, M. \& MARSHALl, R. B. (1990). DNA relatedness among strains of Leptospira biflexa. International Journal of Systematic Bacteriology 40, 231-235.

Ramadass, P., Jarvis, B. D. W., Corner, R. J. \& Marshall, R. B. (1992). Genetic characterization of pathogenic Leptospira species by DNA hybridization. International Journal of Systematic Bacteriology 42, 215-219.

SAitou, N. \& Nei, M. (1987). The neighbour joining method: a new method for constructing phylogenetic trees. Molecular Biology and Evolution 4, 406-425.

SAmbrook, J., Fritsch, E. \& Maniatis, T. (1989). Recovery and purification of DNA fractionated on agarose gels. In Molecular Cloning: A Laboratory Manual, pp. 6.22-6.35. Cold Spring Harbor, NY: Cold Spring Harbor Laboratory.

Schmid, G. P., Steere, A. C., Kornblatt, A. N., Kaufmann, A. F., Moss, C. W., Johnson, R. C., Hovind-Hougen, K. \& Brenner, D. J. (1986). Newly recognised Leptospira species ('Leptospira inadai' serovar lyme) isolated from human skin. Journal of Clinical Microbiology 24, 484-486.

Segers, R. P. A. M., van Gestel, J. A., van Eys, G. J. J. M., van DeR Zeisst, B. A. M. \& GaAstra, W. (1992). Presence of putative sphingomyelinase genes among members of the family Leptospiraceae. Infection and Immunity 60, 1707-1710.

Stanton, T. B., Jensen, N. S., Casey, T. A., Tordoff, L. A., DewhiRst, F. F. \& PASTER, B. J. (1991). Reclassification of Treponema hyodysenteriae and Treponema innocens in a new genus, Serpula hyodysenteriae comb. nov. and Serpula innocens comb. nov. International Journal of Systematic Bacteriology 41, 50-58.

Templeton, A. R. (1983). Phylogenetic inference from restriction endonuclease cleavage site maps with particular reference to the evolution of humans and the apes. Evolution 37, 221-244.

Whiley, R. A., Fraser, H. Y., Douglas, C. W. I., Hardie, J. M., Williams, A. M. \& Collins, M. D. (1990). Streptococcus parasanguis sp. nov., an atypical viridans Streptococcus from human clinical specimens. FEMS Microbiology Letters 68, 115-122.

WOESE, C. R. (1987). Bacterial evolution. Microbiological Reviews 51, $221-271$.

Yasuda, P. H., Steigerwalt, A. G., Sulzer, K. R., Kaufmann, A. F., Rogers, F. \& BRENNER, D. J. (1987). Deoxyribonucleic acid relatedness between serogroups and serovars in the family Leptospiraceae with proposals for seven new Leptospira species. International Journal of Systematic Bacteriology 4, 407-415. 